\title{
BEBERAPA TEORI DAN PENDEKATAN SEMANTIK
}

\author{
Herlina Ginting ${ }^{1}$, Adelina Ginting ${ }^{2}$ \\ *1 Penulis 1 \\ *2 Penulis 2
}

Fakultas Ilmu Budaya USU, Herlinaginting7@gmail.com dan FKIP UNIKA ST.Thomas adelinaginting57@gmail.com

\begin{abstract}
Abstrak
Tujuan penulisan makalah ini untuk mendeskripsikan pengertian semantik, beberapa teori dan pendekatan. Data dikumpulkan dari pendapat beberapa ahli linguistik. Metode pengumpulan data dilakukan dengan metode kepustakaan yaitu menulusuri pengertian semantik, teori dan pendekatan semantik dari beberapa buku-buku linguistik. Hasil penelitian menyimpulkan ada beberapa pendapat tentang semantik behavioris, semantik generatif, semantik struktural, semantik deskriptif, semantik leksikal, semantik logika, semantik gramatikal, dan semantik historis.
\end{abstract}

\section{Kata Kunci: Teori, Pendekatan, Semantik}

\begin{abstract}
The purpose of this study is to describe the semantics definitions, theories and approaches. The data was collected by some linguists' theory. Data collecting was done by library research which is exploring the semantics definitions, theories and approaches by some linguistics books. The results concluded that there are several theories about behavioral semantics, generative semantics, structural semantics, descriptive semantics, lexical semantics, logical semantics, grammatical semantics, and historic semantics.
\end{abstract}

\section{Keywords: Theory, Approach, Semantics}

\section{Pendahuluan}

Pada buku kedua Chomsky yang terbit pada 1965 menyatakan bahwa semantik adalah komponen dalam linguistik yang dapat disejajarkan dengan komponen lain, seperti: fonologi dan sintaksis. Untuk menentukan sebuah makna dalam kalimat ditentukan oleh komponen semantik. Oleh karena itu, Chomsky mengatakan betapa pentingnya

ISSN 15421-71667

Volume 2 Nomor 2 Desember 2019 semantic dalam ilmu linguistik. Pernyataan Chomsky sangat menggugah para pengamat bahasa semakin memperhatikan semantik sebagai satu tatanan dalam linguistik.

Semantik merupakan salah satu cabang linguistik. Semantik dalam bahasa Inggris disebut semantics. Kata semantics berasal dari bahasa Yunani yaitu dari kata sema (kata benda) yang berarti 'tanda; semelon (kata kerja) berarti 'menandai'. Istilah semantic 
sudah ada pada abad ke-17. Misalnya dalam kelompok kata semantics philosophy. Istilah ini kemudian lebih diperkenalkan lagi oleh oraganisasi fisiologi Amerika (American Philological Association) Pada atahun 1894 yang berjudul Reflected meanings a point in semantics. Dibandingkan dengan cabang linguistic alinnya, seperti : fonologi, morfologi dan sintaksis maka semantic ini adalah cabang yang paling tertinggal. Hal ini dapat dipahami karena dalam semantic untuk membicarakan makna banyak yang harus dipecahkan.

Apakah yang dimaksud dengan semantik? Berikut ini diuraikan beberapa pendapat dari para ahli.

"Semantik adalah bidang linguistic yang mempelajarai hubungan antara tanda-tanda linguistic dengan hal-hal yang ditandainya atau dengan kata lain bidang studi dalam linguistic yang mempelajari makna dalam bahasa" (Chaer, 1994:2)

"Semantik adalah bagian dari tata bahasa yang memiliki makna dalam bahasa tertentu, mencari asal mula dan perkembangan dari arti suatu kata" (Kraf)

"Semantik adalah 1. Bagian struktur bahasa yang berhubungan dengan makna ungkapan dan juga dengan struktur makna suatu wicara. 2. System dan penyelidikan makna dan arti dalam suatu bahasa atau bahasa pada umumnya" (Kridalaksana, 1993:193).

"Semantik adalah cabang linguistik yang mengkaji dan meniliti makna dari satuansatuan vokalbuler yang mengacu pada hubungan makna antara satuan-satuan dimaksud" (Ridwan, 2002:61)

Leherer (1974:1) mengatakan "Semantik adalah studi tentang makna" (Pateda, 1996:6).

\section{ISSN 15421-71667}

Volume 2 Nomor 2 Desember 2019
Dalam Ensiklopedia Britanika (Encyclopedia Britanica Vol. 20, 1965:313) yang terjemahannya "Semantik adalah studi tentang hubungan antara suatu proses mental atau symbol dalam aktivitas bicara (Pateda, 1996:7).

Verhaar juga mengatakan (1983:124) "Semantik berarti teori makna atau teori arti" (Pateda, 1996:7)

Dari pendapat di atas dapat kita lihat bahwa semantik ini ilmu atau cabang linguistik yang memeplajarai makna. Sekarang, apa yang dimaksud dengan makna? Seperti yang dikemukakan sebelumnya, jika membicarakan makna banyak hal yang harus dipecahkan. Salah satu diantaranya adalah pengertian makna itu sendiri.

(a) Conceptual theory

Menurut teori ini makna adalah mental image si pembicara dari subjek yang dia bicarakan.

(b) Reference atau Corrsepondence theory

Menurut teori ini bahwa makna adalah hubungan langsung antara simbol-simbol linguistic dengan acuannya.

\section{(c) Contextual theory}

Teori ini berusaha menerangkan makna kata-kata dengan perantaraan sanding kata (collocation) yang biasa ditemukan. Sebagai contoh kata tentara. Kata ini dijelaskan dengan perantaraan sanding kata yang umum dipakai atau berkaitan dengan kata tentara itu, seperti: perang, garis depan, komandan, kopral, pistol, jarak tembak, parit, pertahanan dan sebagainya. Dengan kata-kata ini kosa kata tentara memang lebih erat dibandingkan dengan kosa kata seperti rujak cuka, ternak itik 
atau tuan profesor dan sebagainya. Contohcontoh ini membentuk yang disebut collocational seis atau perangkat sanding kata. Kesulitan dalam teori ini adalah tidak sistematikanya dalam menangani data. Dengan demikian collocation ini dirasa tidak merupakan jajahan linguistik, tapi lebih cocok dijelajahi para ahli psikologi dan retorika

(d) Field theory

Teori ini menafsirkan kaitan makna antara anggota-anggota dalam kesatuan bidang semantick tertentu.

\section{(e) Componential analysis theory}

Teori ini mempelajarai bagaimana seperangkat kata atau istilah terbentuk dari ciri-ciri semantik umum. Atau dengan kata lain, menganalisis seperangkat kata-kata yang berhubungan ke dalam komponen terkecil dari maknanya, seperti paman kepada komponen laki-laki, ayah, dan sebagainya. Dengan analisis ini kita bisa mempelajari bagaimana para penutur bahasa menggunakan seperangkat kosa kata untuk mengklasifikasikan objek dengan mengacu kepada parameter tertentu dari makna (parameter adalah ciri pemerlain atau penentu).

(f) Combinaterial Semantics atau Semotactics

Teori ini menyelidiki arti leksis dari setiap butir kata juga penyusunan sintaksisnya.

(g) Generative Semantics
Teori ini mencoba menyimpulkan maknamakna dasar dari kalimat dan lalu mentransformasikan makna-makna ini ke dalam ujaran/kalimat nyata (performance). (Alwasilah, 1983:145-146).

\section{Pembahasan}

Para linguist membahas semantic dari berbagai sudut pandang. Hal ini dilakukan untuk memenuhi kebutuhan dalam bidang makna sehingga timbullah bermacam-macam teori semantk.

\section{A. Semantik Behavioris}

Aliran behavioris dikembangkan oleh J.B. Watson. Aliran ini menganut sikap umum yaitu:

1) Tidak selalu yakin dengan istilahistilah bersifat mentalistis berupa mind, concept, dan indra.

2) Tidak ada perbedaan esensial antara tingkah laku manusia dan tingkah laku hewan.

3) Mementingkan faktor belajar dan kurang yakin dengan faktor-faktor hewan.

4) Mekanismenya atau determinasinya.

Menurut Polmer dan Pavlov
dalam penelitiannya, semantik
behavioris dipengaruhi oleh psikologi.
Paham aliran behavioris secara umum
ditandai dengan hubungan antara
rangsangan dan reaksi yang
digambarkan dengan

$\mathrm{S} \longrightarrow \mathrm{R}$ 
Makna berada diantara stimulus dan respon. Makna ditentukan oleh situasi yang berarti ditentukan oleh lingkungan sehingga makna hanya dapat dipahami jika ada data yang diamati. Misalnya seorang ibu berkata "Mam.... Mam...." dan bersamaan dengan ini si ibu menyuapkan makanan ke dalam mulut bayi. Karena hal ini dilakukan secara berualng-ulang maka si bayi dapat memahami kegiatan memasukkan makanan ke dalam mulut dan mnegunyah sesuatu disebut makan. Contoh lain misalnya: seorang anak yang mengadahkan tangannya kepada seorang ibu, kemudian si ibu itu memberikan sesuatu maka bila ada yang mengamatinya maka ia dapat memahami anak tersebut sedang meminta. Maka dapat disimpulkan pemahaman makna diperoleh melalui peroses pengamatan.

\section{B. Semantik Generatif}

$\begin{array}{lc}\text { Semantik generatif ini } \\ \text { dipelopori oleh } & \text { murid-murid } \\ \text { Chomsky antara lain (Lakoff, Postal, }\end{array}$ Mecauly dan Kiparsky) mereka memisahkan diri dari kelompok Chomsky menjelang dasawarsa tujuh puluhan. Pemisahan diri itu didasarkan pada rasa ketidakpuasan terhadap guru mereka. Chomssky berpendapat bahwa semantik mempunyai eksistentsi yang berbeda dengan sintaksis, dan struktur batin tidak sama dengan struktur semantic. Sementara menurut Lokoff dan teman-temannya bawwa struktur semantik dan untuk menghubungkan keduanya cukup dengan kaidah transformasi saja. Bukan dengan bantuan kaidah sintaksis dasar, kaidah proyeksi, dan kaidah fonologi seperti pernah diajarkan oleh Chomsky pada mereka. Oleh karean itu sintaksis dalam semantik sebaiknya diselidiki secara bersamaan karena keduanya adalah satu. Struktur semantic itu berupa ikatan tidak berkala antara predikat dengan seperangkat argument dalam suatu proposisi. Struktur logika itu dapat digambarkan seperti berikut.

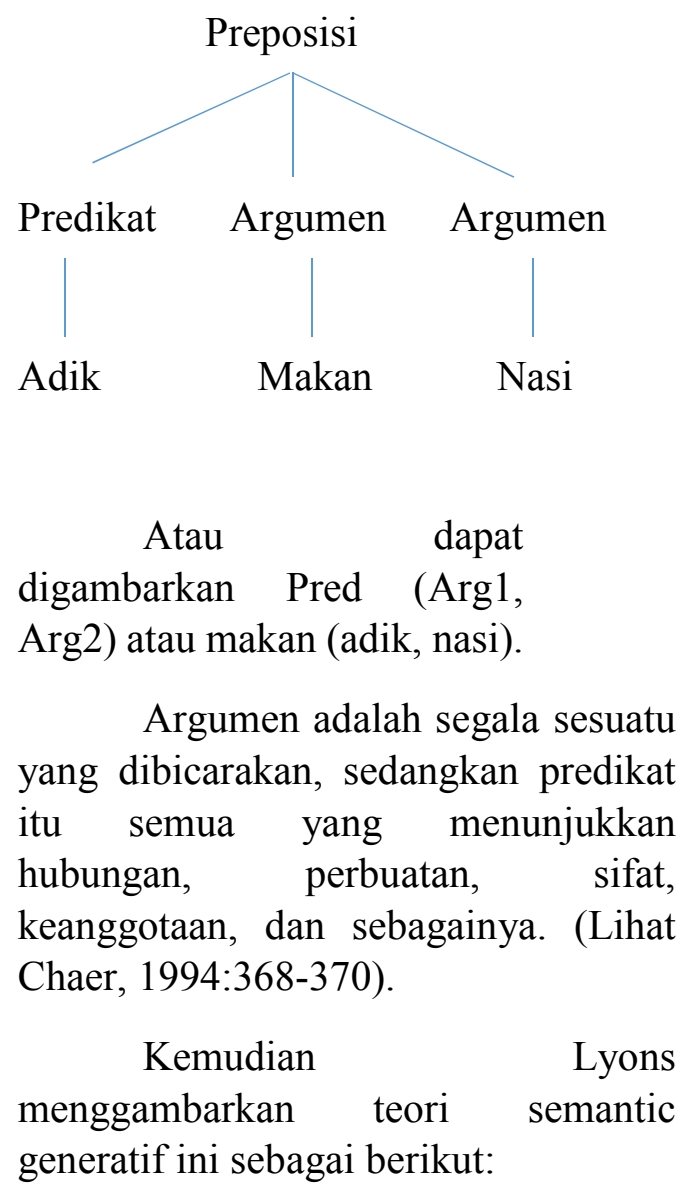




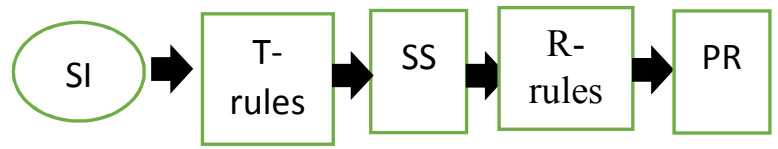

Keterangan:

$\mathrm{SI}=$ Semantic Interpretations

$\mathrm{T}-$ rules $=$ Transformation rules

$\mathrm{SS}=$ Surface Structure

R-rules $=$ Phonological rules

$\mathrm{PR}=$ Phonological Representation

Jadi, teori semantic generatif

lebih banyak membicarakan makna yang muncul dalam kalimat.

\section{Semantik Struktural}

Aliran struktural dipelopori oleh Ferdinand De Saussure (1857-1913). Ia mengemukakan pendapatnya untuk mengembangkan linguistik sebagai sains, seperti:

a. Perbedaan la langue, la parok, la lawgage

b. Pengembangan linguistik diakronis dan sinkronis

c. Lambing linguistic seperti arti psikis mempunyai dua bagian yang tak terpisahkan yaitu: konsep (signifie) dan inti bunyi (singifiant) Konsep $=$ Signifie $=$ Lambang linguistik

Inti bunyi $=$ significant (linguistic sign)

d. Hubungan assosiatif dan sintagmatis

e. Nilai linguistik, isi dan signifikasi
- Nilai linguistik mencakup dua segi yaitu segi konseptual ialah konsep atau pikiran yang belum konkrit.

- Ada dua nosi yang berkaitan dengan konspetual yaitu signifikasi dan isi.

- Tiga macam nosi tentang arti

(1) Nilai linguistik yaitu arti linguistik yang didefenisikan sebagai suatu totalitas dari system lambing linguistik.

(2) Signifikasi yaitu arti referensial dari lambing-lambang linguistik

(3) Isi (content) yaitu arti yang didefenisikan sebagai jumlah kesluruhan dari nilai linguistic dan signifikasi.

Semantik struktural (Lihat Kridalaksana, 2001:194) adalah:

1. Istilah umum untuk pendekatan kepada semantik yang menekankan hubungan makna antara kata atau kelompok kata dan bukan pada aspek konseptual atau referensi dari makna,

2. Penyelidikan antar hubungan makna berdasarkan pada anggapan bahwa perbedaan makna ini jelas batasannya tergantung dari kontraskontras relative yang ada dalam bahasa.

Para linguis struktural beranggapan bahwa apda unsur fonem tidak ada makna tetapi dapat membedakan makna. Contoh /c/ dan /j/ $=>$ kalau beridiri sendiri dia tidak bermakna seperti cari dan jari maka /c/ dan $/ \mathrm{j} /$ sudah berfungsi membedakan 
arti pada unsur morfem ada yang bermakna dan ada yang hanya mengakibatkan makna (munculnya makna); pada unsur kata memang ada yang disebut makna leksikal: pada unsur frasa ada makna; yaitu makna frasa itu sendiril pada unsur klausa terdapat makna yaitu makna klausa itu sendiri; pada unsur kalimat terdapat makna yaiut makna gramatikal; dan pada unsur wacana terdapat makna wacana (Pateda, 1996:77).

\section{Semantik Deskriptif}

Semantik deskriptif membicarakan makna yang sekarang berlaku. Makna kata ketika kata itut untuk pertama sekali muncul tidak lagi diperhatikan. Misalnya:

Kata pura dalam bahasa Indonesia bermakna 'tempat beribadat bagi umat Hindu Dharma' dan bukan bermakna lain misalnya dalam bahasa Minangkabau yaitu:

a. Pundi-pundi dari kain; kantung; dompet

b. Bursa

c. Dana dan juga bukan kata pura yang bermakna istana

\section{E. Semantik Leksikal}

Semantik leksikal adalah kajian semantik yang lebih meluas apda pembahasan sistem makna yang terdapat dalam kata. Semantik leksikal memperhatikan makna yang terdapat di dalam kata itu sendiri. Kamus sangat membantu dalam pencarian makna suatu kata.
Misalnya kata basis yang maknanya: 1. alas, dasar, 2. garis alas pada segitiga, 3. pangkalan perang dimana serangan dilakukan. Pateda (1996) membahas semantik leksikal menjadi beberapa bagian yaitu: 1 . Pengertian makna, 2. makna dalam kata, 3. Perubahan makna, 4. Sekitar makna

Pateda (1985) membahas makna dalam kata terdiri dari:

(1) Makna dalam leksem

(2) Makna panduan leksem

(3) Maknakata bebas

(4) Bentuk yang mengakibatkan makna

(5) Makna kata berimbuhan

(6) Makna kata berulang

(7) Makna kata majemuk

(8) Makna kata terikat konteks kalimat

(9) Makna akronim

(10) Makna singkatan

(11) Makna bentuk yang diplesetkan

Sedangkan perubahan makna terdiri dari:

(1) Akibat perubahan lingkungan

(2) Akibat perubahan pertukaran tanggapan indera

(3) Akibat gabungan leksem

(4) Akibat tanggapan pemakai bahasa

(5) Akibat assosiasi

(6) Akibat perubahan bentuk

(7) Perluasan makna

(8) Pembatasan makna

(9) Melemahkan makna

(11) Lambing tetap acuan berubah

(12) Makna tetap lambing berubah

Pada sekitar makna membahas tentang:

(1) Ambiguitas

(2) Hoponimi 
(3) Hiperhimi

(4) Polisemi

(5) Sinonimi

(6) Entuk

(7) Makna dalam peribahasa dan ungkapan

(8) Makna dalam gaya bahasa

(9) Hubungan mkana

Makna dalam pemakaian

Medan makna

\section{F. Semantik Logika}

Lyons (I, 1997:139) mengatakan "semantik logika adalh cabang logika modern yang berkaitan dengan konsep-konsep dan notasi simbolik dalam analisis bahasa. Semantik logika mengkaji sistem makna yang dilihat dari logika seperti yang dalam matematika yang mengacu kepada pengkajian atau penafsiran ujaran, terutama yang dibentuk dalam sistem logika (Pateda 1996:75). Semantik logika membahas makna proporsi yang dibedakan dari kalimat, sebab kalimat yang berbeda dalam bahasa yang sama dapat saja diujarkan dalam proporsi yang sama, sebaliknya sebuah kalimat dapat diujarkan dalam dua atau lebih proporsi. Proporsi boleh benar, boleh salah dan lambing disebut variable proposisional dalam semantik logika. Misalnya p,q,r, dapat berupa

- Negasi yang dilambangkan dengan $\mathrm{p},-\mathrm{q},-\mathrm{r}$

- Konjungsi yang dilambangkan dengan $-\mathrm{p}$ dan $-\mathrm{q}$ atau $\mathrm{p}-\& \mathrm{q}$

- Implikasi yang dilambangkan dengan $\mathrm{p}=>\mathrm{q}$

- Eqivalen yang dilambangkan dengan $\mathrm{p}=\mathrm{q}$

\section{G. Semantik Gramatikal}

ISSN 15421-71667

Volume 2 Nomor 2 Desember 2019
Semantik gramatikal adalah kajian semantik mengenai makna yang terdapat dalam suatu kalimat. Verhaar (1983:9) mengatakan "Semantik gramatikal lebih sulit dianalisis". Misalnya : Daerah itu aman dan masih terkendali. Munculnya kata terkendali di akhir kalimat di atas mengubur makna aman dalam suatu kalimat. Kata terkendali artinya huru-hara, gangguan keamanan, masih dapat dikendalikan. Dengan demikian makna kata aman berubah karena kata itu berada dalam satuan kalimat.

\section{H. Semantik Historis}

Semantik historis mengkaji Sistem makna dalam rangkaian waktu bukan perubahan bentuk kata. Contoh: Kata juara, dahulu bermakan pengatur pesta atau hakim apda waktu menyambung ayam, kini makna hakim pada waktu menyambung ayam telah dilupakan orang dan sekarang lebih banyak dihubungkan dengan orang yang mendapat peringkat teratas dalam pertandingan dan perlombaan.

\section{KESIMPULAN}

Para linguis membaas semantik dari berbagai sudut pandang. Hal ini dilakukan untuk mencapai makna yang mereka (orang lain) butuhkan. Oleh karena itu, kita dapat menemukan berbagai teori semantik seperti; semantik behavioris, semantik generatif, semantik struktural, semantik deskriptif, semantik leksikal, semantik logika, semantik, gramatikal, semantik historis.

\section{Daftar Bacaan}


Alwi, Hasan dkk. 2003. Tata Bahasa Baku

Bahasa Indonesia. Jakarta: Balai Pustaka

Arifin, Zenal dan S. Amran Tasai. 2002.

Cermat Berbahasa Indonesia Untuk

Perguruan Tinggi. Jakarta: Akademika

Pressindo

Badudu, J. S. 1983. Bahasa Yang Baik dan

Benar. Jakarta: Gramedia

Chaer, Badul dan Ceeri Agustina. 2001.

Sosiolingistik. Jakarta: Rineka Cipta

Efendi, Rustam Amir. 2005. "Catatan

Kuliah". Medan: USU

Kridalaksana, Hari Murti. 1982. Fungsi dan

Sikap Bahasa. Ende, Flores: Nusa Indah

Kridalaksana, Hari Murti. 2001. Kamus

Linguistik. Jakarta: Gramedia Pustaka Utama

Koelan. 1998. Filsafat Bahasa, Masalah dan

Perkembangannya. Yogyakarta: Paradigma

Moeliono, Anthon M. 1991. Santun Bahasa.

Jakarta: Gramedia

Sumarsono dana Paina Partana. 2004.

Sosiolingiustik. Jakarta: Sabda

Tollefson, James W. 1991. Planning

Language, Planning Inequality. London:

Longman

Trudgill, Peter. 1975. Accent Dialect and The

School. London: Edward Arnold Ltd 